DOI: http://dx.doi.org/10.33846/hn31101

http://heanoti.com/index.php/hn

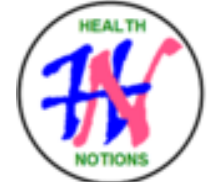

CASE REPORT

URL of this article: http://heanoti.com/index.php/hn/article/view/hn31101

\title{
Psychiatric Assistance at Cataract Juvenile
}

\author{
I Gusti Ayu Indah Ardani ${ }^{1}$, Yunias Setiawati ${ }^{2(\mathrm{CA})}$, Joni Wahyuhadi ${ }^{3}$ \\ ${ }^{1}$ Psychiatrist, Department Psychiatry, Faculty of Medicine, Universitas Airlangga, Indonesia; \\ Igaindah@yahoo.com \\ ${ }^{2(\mathrm{CA})}$ Psychiatrist Consultant, Department Psychiatry, Faculty of Medicine, Universitas Airlangga, Indonesia; \\ Junias.Setiawati@gmail.com (Corresponding Author) \\ ${ }^{3}$ Department of Neuro-surgery, Faculty of Medicine, Universitas Airlangga, Indonesia; \\ joni.wahyuadi@yahoo.com
}

\begin{abstract}
Background: Psychiatric assistance is required in the integrated handling of physical health disorders in the field of other disciplines known as CLP. A collaborative approach to the field of psychiatry with other scientific disciplines in accordance with WHO health criteria that includes physical and mental health for improving health and quality of life. Case presentation: A boy, 8 years, was consulted from the Ophthalmology Department with Right eye cataract juvenile, and left eye ptisis bulbi to give pre-operative psychological assistance for eye assessment and diagnostics. Patient also complained the blurred vision since last year and cannot see anything since 10 months ago. The current condition represents the patient cannot speak, often screams, likes to injure his head and scratch his face. Patients treated in the pediatric's ward with global developmental delay. Patients were also consulted to the child psychiatry section with childhood autism, audiology, nutrition and metabolic diseases of children, pediatric neurology, and finally collaboration with the Surabaya City Health Office for a follow-up management plan. Conclusions: Child psychiatrist as a liaison, interacting with multidisciplinary medical or rehabilitation teams, families, schools, community and local city government are beneficial in the management of child disorders and improving family wellbeing.
\end{abstract}

Keywords: cataract juvenile; autism; psychiatric assistance; consultation liaison psychiatry (CLP)

\section{INTRODUCTION}

\section{Background}

Visual impairments with other medical disorders have a significant impact on a child's development and mental wellbeing. The role of the psychiatrist is like a multidisciplinary liaison in carrying out evaluation and therapy, enables comprehensive integration to develop diagnostic formulations ${ }^{(1)}$.

The Department of Ophthalmology as a leader collaborates with other section specialists to handle a complex case. The Department of Psychiatry-The Child and Adolescent Psychiatry Subdivision carries out psychological assistance to children and families.

The holistic view explains it is necessary to take a mind body approach to the human organization invisibly psychosomatic. Psychiatric assistance aims to bridge the patient's physical disorders and help families recognize and deal with children's disorders, relieve family tension, improve communication and family wellbeing. 


\section{CASE PRESENTATION}

A boy, 8 years 7 months, not yet in school, was consulted from the Department of Ophthalmology with right eye suspect cataract juvenile, right eye observation of corpus vitreous, and left eye ptisis bulbi to give preoperative psychological assistance for eye assessment and diagnostics.

Patient complained the vision of both eyes blurred since last year (when his parent got divorce) and cannot see anything since 10 months ago. The current condition represents the patient cannot speak, often screams, always injure his head and scratch his face, have no appetite and have trouble sleeping. Patients are much calm down when taken for a walk.

Patients treated in the Melati Ophtalmology's ward and consulted to the child psychiatry section, audiology, nutrition and metabolic diseases of children, pediatric neurology, and collaboration with the Surabaya City Health Office for a follow-up management plan.

The patient's past medical history consisted of tuberculosis disease, delayed milestone, kwashiorkor and severe stunted, already had therapy, but not routinely controlled. The psychiatric conditions was diagnosed with childhood autism, received risperidone therapy, vitamin B6, vitamin B12 and folic acid, also not routinely controlled and not obtaining medication regularly.

The patient remains the third of four children, the planned child. Spontaneous labor with birth weight 2600 grams and body length 50 centimeters. No signs of abnormality were detected. Food intake according to his age. Complete basic immunization in Puskesmas.

The patient development based on his mother observations from birth to age 1.5 years old was in normal range, but the development after that until now there was no significant change. The patient is still wearing pampers, defecating and urinating in pampers.

From birth the patient is cared for by his mother and prefers with his mother. But after his parent divorce, the patient was taken by her father for a while because of economic problems. Since then the patient's vision began to decline and initially had fallen. When the patient was cared for by the mother, the patient was still often trained to talk. Patient can merely play with his mother and siblings, appeared hyperactive, communication disruption and social interaction.

Current life situation based on home visit, the house size was $4 \times 3$ meters that contains with many items, populated by 2 adults and 2 children, located in a small and damaged street and low income family.

Examination revealed the body weight 18 kilograms, general examination were within normal limits, drooling, glasgow coma scale's score was XX6 (closed both eyes, cannot speak yet).

On psychiatric examination, general impression was a thin boy and always held; limited verbal contact, no eye contact; clear awareness; mood and affect inadequat; orientation, thinking process, intelligence attention, and perception cannot be evaluated yet; will within normal limits; psychomotor increased; child defense mechanism was acting out; child's affection and aggression stimulation and control was if the desire is not fulfilled, the patient will rebel; child fantasy about dream and desire cannot be evaluated yet, the patient likes to hold a snack wrapper that can make a sound; superego was ideal ego and moral value; children's self-concept was currently closer to father and identification of identity in a masculine direction; awareness of the problem still not aware of the problem of the disease; neuromuscular integration of fine motor coordination was still lacking and a delay in gross motor development.

Laboratorium examination showed a haemoglobin of $11.6 \mathrm{~g} / \mathrm{dL}$ (normal range 11.5-15.5 g/dL), random glucose of $93 \mathrm{mg} / \mathrm{dL}$ (normal range <140 mg/dL), albumin $4.2 \mathrm{~g} / \mathrm{dL}$ (normal range 3.7-5.5 g/dL), blood urea nitrogen (BUN) of $19 \mathrm{mg} / \mathrm{dL}$ (normal range $5-25 \mathrm{mg} / \mathrm{dL}$ ), Immunoglobulin-G (IgG) rubella of $72.5 \mathrm{mg} / \mathrm{dL}, \mathrm{IgG}$ cytomegalovirus (CMV) of $32 \mathrm{mg} / \mathrm{dL}$.

Noncontrast computed tomography (CT) of the head showed left eye retinoblastoma. Ultrasonography (USG) of the eyes showed right eye secondary long standing retinal detachment et causa posterior uveitis (panuveitis) and left eye ptisis bulbi. Chest x-ray showed no abnormal sign.

\section{DISCUSSION}

The Department of Ophtalmology Sciences collaborated with other fields in the case with many problem lists, such as ophtalmology are right eye suspect juvenile cataracts, right eye observation corpus vitreum, right eye secondary long standing retinal detachment et causa posterior uveitis (panuveitis) and left eye ptisis bulbi; psychiatry is speech delay in childhood autism; pediatric are developmental delay, microcephaly, kwashiorkor, stunted, Rubella and CMV infection; and psychosocial problems are divorce patients and family economic problems.

Health conditions of children with disabilities consisting of various types of disabilities. They are a group that vulnerable to various threats. They have the same right to obtain health services. This is stated in Law 
Number 35 of 2014 concerning Amendment to the Law on Child Protection Number 23 of 2002, and Law Number 36 of 2009 concerning Health and Law Number 11 of 2011 concerning the Convention on the Rights of Persons with Disabilities ${ }^{(2)}$.

Primary care is community-based personal health care, such as at least one visit each year, child care service providers as a source for handling a child psychosocial problems, and concept of primary care obtains team-based home medical treatment led by a private doctor. It is estimated that $15-25 \%$ of pediatric patients have mental health disorders. Child Psychiatrists and Pediatric Care Providers (PCP) are sources for primary identification and treatment of common health problems ${ }^{(3)}$.

Congenital visual impairment can be due to genetic anomalies or impaired development of the vision system. Children with visual impairments frequently experience social integration and communication disorders and are often suffer autistic disorders. This is because the ability of visualization is limited, causing differences in perception ${ }^{(4)}$.

The patient's prognosis is poor because of childhood autism as well as visual impairment so that he does not quite accept complex instructions. Child psychiatrists perform integrated care, collaborating with the Department of Ophtalmology as a leader, Pediatric Department, and Surabaya City Health Office formed in the CLP Team activities for diagnostic and case management.

\title{
Ophthalmology management
}

1. Patients planned for the examination procedure under general anesthesia,

2. If cataracts are proven, cataract extraction and evaluation of the posterior segment of the eye were performed.

\section{Psychiatric management}

1. Psychopharmaca to reduce anxiety is Haloperidol 2 x $0.5 \mathrm{mg}$, Klobazam 1 x $1 \mathrm{mg}$, Depakote 1 x $250 \mathrm{mg}$, the drugs were stopped 1 day before surgery,

2. ABA modification to reduce harmful behaviors and create positive behaviors so that children can be accepted by the environment and increase self-esteem and self-reliance,

3. Parental Psychoeducation for understanding of children's limitations, building good communication and representing an active role in the child's therapeutic process.

\section{Pediatric's nutrition management}

\author{
Requirement RDA based on Heigh Age \\ Total : $90 \times 19=1710 \mathrm{kkal}$ \\ Calories $\quad: 80-100 \%$ \\ Fluid $\quad:(90-100) 16.1=1449-1771 \mathrm{ml}$ \\ Protein $\quad: 1.2 \times 19=22.8 \mathrm{~g}$ \\ Rute Oral : children diet formula $900 \mathrm{kkal}$, milk 5 x $100 \mathrm{ml}=500 \mathrm{ml} \sim 500 \mathrm{kkal}$ \\ Calory Total $1400 \mathrm{kkal} \sim 82 \%$ RDA Total
}

\section{Action Plan Phase}

1) Acute Stage:

a) Opthal Diganostic

b) Uveitis: Steroid therapy $\rightarrow$ not definitively improve vision function

2) The treatment stage: Rubella, CMV infection

a) Work up rubella syndrome: Echo, THT

b) Nutritional problem

c) Polyclinic care for emotional disturbances of patients

3) Rehabilitation Stage: assisting outpatient's growth and development, to the Rehabilitation Outpatient for Speech Therapy and Occupational Therapy when the hearing results are satisfactory and the patient is cooperative.

According to the representative study, almost 1 in 4 children aged 5-15 in the US live in a family environment with a modest level of safety. An environment free from violence and threats is substantial thing for children. The strategy is focused on helping families reduce the exposure to violence that threatens children's safety $^{(5)}$. 
In addition, this treatment team uses psychodynamic concepts and attachment theory in problematic cases. This helps psychiatric consultants to teach team members how to provide help and improve patient approaches. Care team members often have counter transference reactions and are extremely risky to patients and families with limited abilities for mental health ${ }^{(6)}$.

\section{CONCLUSION}

Psychiatric assistance is useful in the management of organic disorders with the aim of recognizing pain, easing family tensions and creating family wellbeing.

\section{REFERENCES}

1. Cardona L. Pediaric Consultation Liaison. In: Martin A, Bloch MH, Volkmar FR. Lewis's Child and Adolescent Psychiatry. 5th ed. Philadelphia: Wolters Kluwer; 2018. p. 2533-2548.

2. MoH-RI. Guidelines for Child Health Services with Disabilities for Health Workers, Pedoman Pelayanan Kesehatan Anak dengan Disabilitas bagi Tenaga Kesehatan. Jakarta: Ministry of Health of Republic of Indonesia; 2014.

3. Bostic JQ, Potter MP, King, RA. Clinical Asessment of Children and Adolescent: Content and Structure. In: Martin A, Bloch MH, Volkmar FR. Lewis's Child and Adolescent Psychiatry. 5th ed. Philadelphia: Wolters Kluwer; 2018. p. 852-897.

4. Rusmil K. Impacts of Child Growth Disorders and Development on Emotional Mental Children, Dampak Gangguan Pertumbuhan Anak dan Perkembangan terhadap Mental Emosional Anak. In: AKESWARI. Mental Well Being for Children Parent and Family. Bandung: AKESWARI; 2014.

5. Turner HA, Merrick MT, Finkelhor D, Hamby S, Shattuck A, Henly M. The Prevalence of Safe, Stable, Nurturing Relationships Among Children and Adolescents. Office of Juvenile Justice and Delinquency Prevention Bulletin. 2017 Sep:1-12.

6. Delgado SV, Strawn JR. The Treatment Team. In: Delgado SV, Strawn JR. Difficult Psychiatric Consultations. New York: Springer; 2014. p. 95-112 